\title{
ICTOPI
}

\author{
UDC 94(477.87)“1953/1964" \\ DOI https://doi.org/10.24919/2308-4863/43-1-1
}

Natália VÁRADI,

orcid.org/0000-0003-4175-4928

Candidate of Historical Sciences,

Associate Professor at the Department of History and Social Sciences Ferenc Rakoczi II Transcarpathian Hungarian College of Higher Education (Berehove, Transcarpathian region, Ukraine) varadinatalia29@gmail.com

\section{THE PLANT CULTIVATION SITUATION OF TRANSCARPATHIA IN THE KHRUSHCHEV ERA (1953-1964)}

After Stalin's death, N. Khrushchev emerged victorious from the political struggle. Then, after the execution of L. Beria, head of the Soviet secret service, communist dictatorship was replaced by a period of total oligarchy. The period between 1953 and 1964 can be seen as the era of "thaw". N. Khrushchev implemented a number of reforms, but the reform era turned into recentralization, causing Khrushchev's failure. Due to its geopolitical situation, Transcarpathia received significant attention from Soviet leaders. The area was of strategic importance in terms of transport from east to west, it was considered a «western gate». The Chop - Batevo area became one of the most important transhipment stations in the Soviet Union. Transcarpathia had been economically integrated into the Soviet system since 1946 and became part of the Ukrainian SSR economy. Planbased management was implemented in all areas of agriculture. Despite the fact that a lot of work was devoted to the political and economic history of Transcarpathia during the "thaw», the peculiarities of the reform of agriculture in the region at this time were not in the center of attention of scientists. The aim of this article is to find out the key features of the plant cultivation situation of Transcarpathia in the Khrushchev era (1953-1964). The key areas of crop production in Transcarpathia during the time of $N$. Khrushchev were domestication of tea and citrus plants, the great Party cereal (corn) program, and growing of vegetables, fruits and grapes. The plan for the domestication of tea and citrus plants failed because the kolkhozes were unable to meet the plans regarding the tea plantations, mostly due to frost damage to the plants. A number of problems arose in corn production as well. Orcharding and viticulture were relatively successful even in the mountain areas. Plan-based Soviet management was unable to satisfy all needs of Transcarpathian crop production during the time of N. Khrushchev.

Key words: Transcarpathia 1953-1964, agriculture, plant cultivation, kolkhoz, sovkhoz, reform.

Наталія ВАРОДІ, orcid.org/0000-0003-4175-4928 кандидат історичних наук, доцент кафедри історії та суспільних дисциплін

Закарпатського угорського інституту імені Ференца Ракоці II (Берегове, Закарпатська оласть, Україна) varadinatalia29@gmail.com

\section{СИТУАЦІЯ В РОСЛИННИЦТВІ ЗАКАРПАТТЯ В ЕПОХУ ХРУЩОВА (1953-1964)}

Після смерті Сталіна переможием політичної боротьби вийшов М. Хрущзов. Потім, після страти Л. Берї, голови радянської спецслужби, комуністична диктатура змінилася періодом тотальної олігархї. Період між 1953 i 1964 рр. можна розглядати як епоху «відлиги». М. Хрущчов здійснив низку реформ, але період реформ переріс у рецентралізацію, шьо спричинило провал М. Хрущова. Завдяки своєму геополітичному становищу Закарпаття привертало увагу радянського керівництва. Район мав стратегічне значення з погляду транспортного сполучення між Сходом $i$ Заходом, його вважали «західними воротами». Район «Чоп - Батєво» став однією з найважливіших перевантажувальних станиій Радянського Союзу. Із 1946 р. Закарпаття було економічно інтегроване до радянської системи та стало частиною народного господарства Української РСР. У всіх галузях сільського господарства впроваджувалося планове управління. Незважаючи на те, щзо політичній та економічній історії Закарпаття в період «відлиги» присвячено багато праць, особливості реформування сільського господарства краю в ией час не потрапляли в центр уваги науковців. Мета статті - з'ясувати основні особливості в становищі рослинництва Закарпаття хрущовської доби (1953-1964). Основними напрямами рослинництва Закарпаття за часів М. Хрущчова були доместикачія чаю та циитрусових, велика партійна злакова (кукурудзяна) програма, вирощування овочів, фруктів і винограду. План доместикації чаю та иитрусових провалився, оскільки колгоспи не змогли виконати плани щодо чайних плантаиій, здебільшого через пошкодження рослин унаслідок морозів. Низка проблем виникла й у виробництві кукурудзи. Садівництво та виноградарство були порівняно успішними навіть у гірських районах. Планове радянське керівництво було не в змозі задовольнити всі потреби закарпатського рослинництва за часів М. Хрущзова.

Ключові слова: Закарпаття 1953-1964, сільське господарство, рослинництво, колгосп, радгосn, реформа. 
Problem statement. After Stalin's death, Nikita Khrushchev emerged victorious from the political struggle, in which three triumvirates took turns. Then, after the execution of Lavrentiy Beria, head of the Soviet secret service (December 23, 1953), communist dictatorship was replaced by a period of total oligarchy. The period between 1953 and 1964 , the era of "thaw", can be seen as a positive decade in the history of the Soviet Union in terms of improvement of living standards and declining dictatorship (Медведев, 1990: 68).

Khrushchev implemented a number of reforms, but the reform era turned into recentralization, causing Khrushchev's failure on October 14, 1964 (Krausz, 2008: 146; Kun, 2006; Медведев, 1990: 68).

Due to its geopolitical situation, Transcarpathia received significant attention from Soviet leaders. The area was of strategic importance in terms of transport from east to west, it was considered a "western gate". The Chop-Batevo area became one of the most important transhipment stations in the Soviet Union (Brenzovics, 2009: 95-96).

Transcarpathia had been economically integrated into the Soviet system since 1946 and became part of the Ukrainian national economy. Plan-based management was implemented in all areas of agriculture.

\section{Literature analysis}

Despite the fact that a lot of work was devoted to the political and economic history of Transcarpathia during the "thaw" (Білоусов B. et al, 1980; Brenzovics 2009; Csanádi, 2004; Oficinszkij, 2010a; Oficinszkij, 2010b; Tokár et al, 2011; Шепа, 1972), the peculiarities of the reform of agriculture in the region at this time were not in the center of attention of scientists.

The aim of this article is to find out the key features of the plant cultivation situation of Transcarpathia in the Khrushchev era (1953-1964).

\section{Results and discussion}

Under pressure from the USSR Ministry of Agriculture and with the tacit consent of the county executive bodies, the collective farms in the region continued to plant tea and citrus fruits. Thus, according to the letter of registration no $17 \mathrm{a}-14143$ dated September 4, 1952, 50 ha of land had been set aside for county collective farms to establish tea plantations in 1953, and a total of 300 ha of tea plantations had to be established between 1953 and 1955 (TRSA. F. P-179. Op. 1. Od. zb. 1685. Ark. 13).

The letter № 1406 from January 29, 1953 by Turianycia I., Chairman of the Executive Committee of the County Council, addressed to the leaders of the collective farms of the four lowland districts Uzhhorod, Mukachevo, Berehove, and Vynohradiv, stated that according to the decree № 1333 adopted by the Soviet Council of Ministers Resolution on 20 January 1953, the county branch of Silhospbank
(Agricultural Bank) was authorized to grant loans to the collective farms in Transcarpathia in 1953 from the credit line set aside for crop production in that year for up to $100 \%$ of the costs for up to 12 years, under the terms of which repayment had to start six years after the disbursement of the loan (TRSA. F. P-179. Op. 1. Od. zb. 1685. Ark. 51).

According to a report from the County Agricultural Directorate in August 1954, the plantations were severely damaged by frost during the winter. The most significant damage occurred in the winter of 1953-1954. Nearly 25 ha of plantations were completely destroyed, and in the other areas $85-90 \%$ of the plants were destroyed, especially in the collective farms in Mukachevo and Irshava districts. In the Uzhhorod district, for example, all the tea plantations in the "Red Partisan" and "Stalin Friendship" collective farms were destroyed (TRSA. F. P-179. Op. 1. Od. zb. 2021. Ark. 72).

However, in May 1955, the county leadership, in the letter No. 762 to the Soviet Ministry of Food, stated its intention to further increase the area of plantations, for the implementation of which it made some new proposals (TRSA. F. P-179. Op. 1. Spr. № 2390. Ark. 11).

Despite the significant damage, Moscow insisted on overcoming the natural and climatic conditions, so, in addition to tea, the number of lemons, orange, fig, pomegranate, date, as well as laurel and eucalyptus plantations increased in Transcarpathia. Experiments with the introduction of citrus fruits were not terminated until 1956 (Oficinszkij R., 2010b: 281). To achieve this goal, even specialists from the Soviet Tea Industry Scientific Research Institute were sent to the region ${ }^{1}$.

Between 1953 and 1961, a capital investment of $127 \mathrm{mln}$ roubles was made for the development of agriculture in Transcarpathia, which was mainly due to bank loans (TRSA. F. P-179. Op. 1. Od. zb. 49. Ark. 23). The kolkhozes received loans; however, actions were proposed to the kolkhozes on how to use the amounts allocated. The special decree contained the distribution of loans to the county's collective farms engaged in tea production. In 1953, 540000 , in 1954, 1,2 mln, and in 1955, 1,6 mln were spent for this purpose (TRSA. F. P-179. Op. 1. Od. zb. 1685. P. 42).

\footnotetext{
${ }^{1}$ An example of this is the letter of the Deputy Minister of Food Supply of the USSR, M. Panasiuk, dated 24 May 1955: «The Ministry of Food Supply sends a team of experts from the Soviet Tea Research Institute of the Ministry of Food Supply and the Soviet Research Institute of Tea and Subtropical Cultivated Plants of the Ministry of Agriculture to increase the area of Transcarpathian tea plantations and to help create 1-2 new tea sovkhozes. Before the said brigade arrives in Transcarpathia, I request nearly a thousand hectares of land to be designated for the creation of a sovkhoz and the team to be assisted in their work ... (TRSA. F. P-179. Op. 1. Spr. № 2390. Ark. 11)».
} 
However, the kolkhozes were unable to meet the plans regarding the tea plantations.

The corn program began in 1954. The soil composition and the local climate allowed the kolkhozes of the region to grow corn very successfully, so by 1955 it had already been cultivated on 25000 ha (Народне господарство, 1957: 51).

According to a resolution adopted by the rnKP Central Committee Plenary in February 1955, $5,2 \mathrm{mln}$ ha of corn were planned to be sown in 1955, of which 4,3 $\mathrm{mln}$ ha were for fodder (Баран, 1992: 27). In 1955, the total corn crop increased by $2700 \mathrm{q}$ and accounted for $49 \%$ of the county's total grain crop (TRSA. F. P-179. Op. 1. Od. zb. 2776. Ark. 80-81). For example, in the "Stalin" collective farm in Storozhnytsia, Uzhhorod district, 57,6 q of corn was harvested on each of the 115 ha; in Velyki Luchky, Mukachevo district, in a collective farm named after Lenin, 45,5 q of cot per ha were harvested on an area of $819 \mathrm{ha}$. Some brigades produced even better results (TRSA. F. P-179. Op. 1. Od. zb. 2776. Ark. 115-116). The archival documents include a number of reports on achievements, success and commitments ${ }^{2}$.

According to the data of the County Agricultural Directorate, the sowing of corn was ordered in the Volovets district in the mountains, a total of 500 ha, and in the Perechyn district in the foothills, 885 ha (TRSA. F. P-179. Op. 1. Od. zb. 2773. Ark. 103).

In 1955, the collective farms in the Svaliava district harvested the most corn - 35,5 q per ha on an area of 390 ha (TRSA. F. P-179. Op. 1. Od. zb. 2776. Ark. 82).

In the coming years, the collective farms made even greater efforts. Corn became a kind of party cereal.

According to Joint Resolution No. 123 of the Central Committee of the Communist Party of Ukraine and the Council of Ministers of the USSR, adopted on February 9, 1961, on measures to achieve higher corn yields in Ukrainian kolkhozes and sovkhozes in 1961, corn had to be grown on a total area of 40000 ha,

\footnotetext{
${ }^{2}$ According to the notification sent by Roman I., the head of the Perechyn Kolhoz-Sovhoz Directorate on April 14, 1954, to M. Kovalenko, Deputy Chairman of the Directorate of Agricultural Production and Food Supply: «In response to your letter No. 571 dated 6 March we would like to inform you that 315 corn growing brigades have been organized in the kolkhoz directorates, of which 14 are mechanized brigades with a minimum labor requirement on a total area of 770 hectares. The brigades undertook to grow corn according to the following expected indicators: 135 brigades with 50 centners per hectare on 2140 hectares; 47 brigades with 51-60 centners on 694 hectares, 6 brigades with $61-70$ centners on 152 hectares; 1 brigade with $81-90$ centners on 20 acres; 1 brigade with 91-100 centners on 25 hectares. We plan to establish 22 chemical laboratories in the kolkhozes. So far, 9 laboratories have been established, 4 of which are operational. In the „Star of Communism” collective farm, the laboratory was equipped and arranged by the Uzhhorod State University. The laboratory of the Velykyi Bereznyi Agricultural Brigade was equipped by the Uzhhorod Radio Factory ...[...] (TRSA. F. P-179. Op. 1. Od. zb. 5683. Ark. 4)».
}

reaching a yield of $60 \mathrm{q}$ per ha (TRSA. F. P-179. Op. 1. Od. zb. 4759. Ark. 19).

In 1961, the farms of the county harvested corn on an area of 18065 ha, yielding 30,5 q per ha, the total yield was $55100 \mathrm{t}$, which is $16100 \mathrm{t}$ more than in the previous year. This year, the largest corn-growing districts, i. e. the Berehove and Vynohradiv districts, did not reach the planned 55 q per ha. The kolkhozes and sovkhozes of the two districts harvested 24,5 and 33,4 q of corn per ha (TRSA. F. P-179. Op. 1. Od. zb. 4812. Ark. 58).

In $1961,27,5$ and 27,9 q of corn per ha were harvested on the farms of the Mukachevo and Uzhhorod districts, which was also well below the county average. In the Mukachevo district, corn accounted for $72 \%$ of the grain grown there, and for $58 \%$ in the Uzhhorod district. It is clear, that farms produced far less grain than expected, which also had an impact on the productivity of livestock farming (TRSA. F. P-179. Op. 1. Od. zb. 5072. Ark. 4-6).

Towards the end of the Khrushchev era, we know the situation of Transcarpathian corn production from the report of the county leadership dated June 17, 1964 . Of course, many of these results only existed on paper. For example, the district of Svaliava, where corn was sown on 700 ha in 1960, had only 4 corn seeders. The "Memory of Ilyich", to which most of the district's plantations belonged, for example, had no seeder machine at all. Half of the farms was unable to do the plowing. In the same

\footnotetext{
${ }^{3}$ It states: «According to the decision of the Central Committee of the Soviet Communist Party adopted at the February 1964 Plenary Session, in February - March 84 mechanized brigades were established on the farms of the county, growing corn with a minimum labor cost on 2933 hectares, with a yield of 55 centners of corn, milk-wax ripe corn on 2030 hectares with a yield of 380 centners, potatoes on 538 hectares with a yield of 150 centners, and sugar beets on 90 hectares yielding 300 centners per hectare. In these areas, manual labor is only $5-7 \%$. Furthermore, the areas under mechanized and other brigades also include 19810 hectares of fodder and silage corn, 2754 hectares of potatoes and some other plantations [...]. In most farms, significant organizational work has been done in setting up and assembling mechanized brigades. The brigades are mostly managed by the best mechanics and producers, they have been assigned the land to be sown, the necessary machines, and the agrotechnical materials have been assembled and handed over to them. Members of the brigades received agrochemical education. Quality seeds, organic and mineral fertilizers were obtained. Due to his excellent work, mention should be made of H. Ladanyi and his brigade in the Lenin kolkhoz of the Mukachevo production cooperative, J. Pitra and his brigade in the "For A New Life" kolkhoz, P. Egreshi and his brigade in the "Rosiya" kolkhoz of the Berehove producing cooperative, K. Popovych and his brigade, in the "Prikordonnik" collective farm of the Khust producing cooperative, Roman V. and its brigade in the "Lenin" collective farm of the Tyachiv producing cooperative, O. Tkalych tractor operator and his brigade in the "Dmitrov" collective farm of the Mukachevo producing cooperative, O. Adam tractor operator and his brigade in the "Borets" collective farm of the Perechyn producing cooperative [...]. The farms in the district are abundant in workforce, but the full range of agricultural machinery is not available and there are not enough chemicals to control weeds on plantations [...]» (TRSA. F. P-179. Op. 1. Od. zb. 5683. Ark. 13-17)
} 
year, the yield of corn was 23 q per hectare. The kolkhozes harvested $25730 \mathrm{t}$ less corn than planned. For example, the kolkhozes of the Irshava district harvested only 999 ha of fodder maize, i. e. $24,7 \%$, out of the 4040 ha sown (TRSA. F. P-179. Op. 1. Od. zb. 4812. Ark. 51-57).

In the 1950's and 1960's, the Soviet leadership covered Transcarpathia with orchards and vineyards. The Ukrainian Communist Party sent a number of draft resolutions to the county executive committee to increase the area of orchards and vineyards, despite the fact that several kolkhoz and district leadership letters stated that the plans were unrealistic and unworkable ${ }^{4}$.

In 1953, orchard and viticulture sovkhozes used 3619 ha of land, of which 1031 ha were arable land, 1246 ha were vineyards, and 856 ha were occupied by orchards (TRSA. F. 1. Op. 1. Od. zb. 2342. Ark. 42).

In 1953 , the income from vegetable production was $14,5 \mathrm{mln}$ roubles, $43,4 \mathrm{mln}$ roubles from tobacco production, and $43,9 \mathrm{mln}$ roubles from fruit growing and viticulture (TRSA. F. P-179. Op. 1. Od. zb. 1628. Ark. 504).

In 1953, the Muzhiyevo winery in the Berehove district had vineyards on 67,8 percent of the 313,2 ha of arable land, i. e. 215,6 ha. 51,8 q of grapes were harvested on each of the 208,5 ha of productive vineyards. In the same year, P. Bodó's brigade harvested $85,9 \mathrm{q}$ per hectare on a total area of 7,3 ha, and L. Máté's brigade harvested $74 \mathrm{q}$ per ha on 4,8 ha. In the same sovkhoz the brigade led by Gönczi Sz. harvested 67,7 q of grapes per ha on 21,6 ha (TRSA. F. P-179. Op. 1. Od. zb. 87. Ark. 33).

After 1953, the collective farms and the sovkhozes planted orchards at an increased pace. 1954 was a record year, as a total of 2700 ha of orchards and vineyards were planted in collective farms that year (TRSA. F. P-179. Op. 1. Od. zb. 2382. Ark. 20-21). 720 ha of vineyards were planted in 1955,1250 in 1956, 2450 in 1957, 2050 in 1958 and 2670 ha in 1959 , i. e. a total of 10100 ha in six years (Шепа, 1971: 30).

In 1954, only 27 q of grapes were harvested per ha. The yield of the fruits was only 24 and that

\footnotetext{
${ }^{4}$ Here is an example of this is from a letter dated 26 July 1956 by the head of the Executive Committee of the Berehove District Council, I. Shchadey: «The district council executive committee and the district office of the Ukrainian Communist Party Executive Committee, togehter with the kolkhoz leaders, discussed in detail the draft resolution of the UCP and the Transcarpathian Regional Executive Committee „On increasing the area of vineyards in the kolkhozes of the Berehove district from 600 hectares to 800 hectares between 1956 and 1960". During the discussion of the draft resolution, the leaders of the kolkhozes expressed their opinion that the kolkhozes did not have enough land to plant more than 600 hectares of vineyards. The executive committee of the district council considers it appropriate to increase the area of vineyards to be planted from 600 to 800 hectares for the collective farms in the district between 1956 and 1960 due to the lack of land suitable for planting grapes in collective farms [...] (TRSA. F. P-179. Op. 1. Od. zb. 2801. Ark. 26)».
}

of the berries only 31 q (TRSA. F. P-179. Op. 1. Od. zb. 2382. Ark. 67).

In December 1955, the collective farms in Transcarpathia owned 4686 ha of vineyards, of which 2810 ha were productive vines and also 14960 ha of orchards, of which 7520 ha were productive. The Sovkhozes had 1800 ha of productive vineyards and 3700 ha of orchards during this period. In the kolkhozes in the Uzhhorod district, for example, 766 ha of vineyards were maintained, of which 428 ha were productive (TRSA. F. P-179. Op. 1. Od. zb. 2382. Ark. 76). The plantations in the district were in poor condition, sparse in most kolkhozes, weeded, and attacked by diseases. In the "Suvorov" collective farm, $35 \%$ of the plants and in the "Soviet Transcarpathia" collective farm, $40 \%$ of the plants died. In the "Mikoyan" collective farm, on 40 ha, $70 \%$ of freshly planted vines died, and the plantations became virtually irreparable. In the Lenin and the Suvorov kolkhozes, the yield loss caused by sooty mold reached $40 \%$ in 1955 . According to statistics, 18 ha of freshly planted vines were destroyed in the kolkhozes of the district. It follows that the kolkhozes and sovkhozes, although constantly expanding the areas intended for fruit production, did not always provide for the proper care of the plantations. In 1955, the collective farms applied nutrient irrigation on 1800 ha of vineyards and 4000 ha of orchards, i. e. 38,6 and $26,7 \%$ of the plantations, respectively. In many collective farms, the vineyards were in a neglected state, in some places $20-25 \%$ of the plants died.

Nevertheless, in August 1955, I. Vash, Secretary of the UCP Transcarpathian County Committee, A. Kirichenko, Secretary of the UCP Central Committee, made the following report ${ }^{5}$.

Thus, the areas intended for growing berries and other fruits continued to expand. On March 1, 1956, the head of the County Agricultural Directorate,

\footnotetext{
${ }^{5}$ It states: «The natural conditions of Transcarpathia, its soil and climate, allow a significant increase in the area of vineyards using infertile arable land and other lands. Over the next five years, at least 10000 hectares of new vineyards can be planted in the county, of which 7,5 thousand in collective farms and 2,5 thousand in sovkhozes. The mentioned plantations will be established in the kolkhozes of Uzhhorod, Mukachevo, Irshava, Berehove and Vynohradiv districts. To do this, between 1954 and 1955, 5 greenhouses with grafting nurseries must be built, each with a capacity of one million seedlings per year, in the following locations: at the agricultural experimental station in the Berehove district, in the planting material producing sovkhoz in the Vynohradiv district, in the Uzhhorod fruit nursery, Mukachevo planting material producing sovkhoz, and in the Irshava district. In order for the necessary propagating material to be available to us in time, we consider it necessary for the Ministry of Agriculture and Food Supply to allocate financial support for the construction of grafting workshops. In addition, the capacity of existing grafting stations should be increased to one million grafts per year [...] A total of 2500 hectares of land should be provided to existing and newly established sovkhozes for vineyards, and a total of 310000 hectares, of which 1800 hectares should be covered by the State Forest Fund, and 1300 hectares from the lands owned by the kolkhozes $[\ldots]$ (TRSA. F. P-179. Op. 1. Od. zb. 2801. Ark. 44-48)».
} 
A. Pylypenko and M. Spivak, the Minister of Agriculture of the USSR, made the report ${ }^{6}$.

The pace of planting forced from above had a negative effect on the quality of planting and the material efficiency of viticulture, delayed the time of harvest, so the land did not bring income.

In order to implement the resolution of the Central Committee of the Soviet Communist Party and the Council of Ministers of the USSR of 30 June 1956 to increase fruit and grape production, the Transcarpathian County Committee of the UCP and the Executive Committee of the County Council adopted another joint resolution "On the increase of the plan to extend vineyard area to 15000 hectares in the kolkhozes and sovkhozes of the county between 1956 and 1960". 14014 ha of vineyards were planned to be planted, including in 1960 (TRSA. F. P-179. Op. 1. Od. zb. 2801. Ark. 5-7). The annual plan exceeded 2800 ha, and even the Rakhiv kolkhoz in the mountain area was required to plant 50 ha of vineyards.

The extent of the plans did not change later. According to a report dated 20 September 1956 by Doroshenko, director of the Batrad MTS in the Berehove district, for example, the five-year (1956-1960) development plan for the vineyards in the Batrad MTS area included the establishment of 250 ha of new vineyards in the following collective farms: "Victory" (30 ha), "Michurin" (10 ha), "Kaganovich" (30 ha), "Engels" (50 ha), "Road to Communism" (30 ha), "Bolshevik" (10 ha), "Red Star" (10 ha), "Lenin's Way" (50 ha), "Truth" (15 ha), "Voroshilov" (15 ha). Over the next five-year period

\footnotetext{
${ }^{6}$ «In its resolution of 22 August 1955, the Central Committee of the Communist Party of Ukraine approved the measures planned for the period 1956 to 1960 for the development of viticulture in the kolkhozes and sovkhozes in Transcarpathia. The measures include the planting of new vineyards in the kolkhozes of the region on an area of 7,5 thousand hectares. The USSR Ministry of Agriculture provided significant assistance to the region in carrying out this task. In the second half of 1955 and in the first quarter of the current year, $10 \mathrm{C}-80$ tractors, 25 plows and $10 \mathrm{KD}-35$ tractors were allocated in the county's MTS-s. In the kolkhozes of the county, 917 hectares of land were plowed, while the area of plantations planned to be planted in 1956 was 550 hectares. Given the importance of the task at hand, the County Directorate of Agriculture and the MTS-s have taken steps to strengthen the viticulture brigades in the collective farms and to train new winegrowers. The Mukachevo Agricultural Technical School organized a 2-month agricultural course for 37 people and a viticulture team training for 32 people. In the districts of the region involved in viticulture, in the six-day trainings of the MTS-s, the employees of the kolkhozes (a total of 635 people) were taught the basics of grafting, as well as the techniques of gardening and tree growing (115 people). Considering the prospects for the development of viticulture in the county and the need to plant new vineyards with quality European varieties (rooted, grafted seedlings) (the cultivation of viticulture has spread in the region) in a resolution dated 1 July, the Ministry of Food Supply ordered the viticultural sovkhozes of the Transcarpathian Agricultural Experimental Station to organize the cultivation of planting material for the kolkhozes and sovkhozes of the region. The task for the sovkhozes is to grow 6,8 million seedlings in 5 years, for which the capacity of the greenhouses set aside for grafting must be expanded to 3600000 grafts per year. The Transcarpathian Experimental Station has to grow 1,84 million seedlings in 5 years [...] (TRSA. F. P-179. Op. 1. Od. zb. 2801. Ark. 1-4)».
}

(1961-1965), an additional 250 ha of new vineyards had to be planted. The kolkhozes needed 500 ha of valuable plantations suitable for the planting of European Izabella grape varieties (TRSA. F. P-179. Op. 1. Spr. № 2801. Ark. 34-36).

On January 1, 1959, there were 27000 ha of orchards and 13200 ha of vineyards in the kolkhozes and sovkhozes of the region. During these years, agricultural and party organizations proclaimed the following slogan: "Let's make Transcarpathia a region of orchards and vineyards!". By 1965, 100000 ha of plantations were planned for Transcarpathia, of which 67000 ha would be orchards and 33000 ha would be vineyards (Oficinszkij, 2010a: 231).

According to a letter sent on 17 January 1959 by I. Romanov, Chairman of the National Economic Council of the Stanislav Economic District of the USSR, to Chairman of the Executive Committee of the Transcarpathian County Council, Harahonych I. ${ }^{7}$

On October 9, 1959, the 9th meeting of the Transcarpathian County Committee of the Ukrainian Communist Party was held, which discussed the role of party organizations in Transcarpathia in the development of fruit production and viticulture. It was stressed at the meeting that the area of vineyards in kolkhozes and sovkhozes increased by 23000 ha in the last five years. Compared to 1949, the area of vineyards increased 3,3 times, while the area of orchards increased 4,4 times.

In 1960, four new sovkhozes were established from some collective farms, specializing in fruit and grape growing. The five specialized sovkhozes that already existed significantly expanded their production activities. All nine sovkhozes belonged to the newly created Soviet People's Economy in Stanislav.

According to the 7-year plan (1959-1965), the kolkhozes were to plant 35700 ha of orchards and 8200 ha of vineyards, while the sovkhozes were to plant 10,0 and 11200 ha respectively. In order to achieve a higher indicator, afforestation plans were extended to forestry farms as well. In 10 districts of the region, the forestry farms had to plant 4000 ha, of which 1500 ha in the Tyachiv district and 1000 ha in the Khust district. In the mountain areas 100 ha were ordered to be planted in the Velykyi Bereznyi and Volovets districts, 200 ha in the Perechyn district, and 300 ha in the Rakhiv district (TRSA. F. P-179. Op. 1. Od. zb. 4058. Ark. 3-21).

\footnotetext{
7 «As agreed upon by the County Executive Committee and according to the plan for the development of viticulture and winemaking in Transcarpathia, winemakers must increase the production of grafted grape planting material to 12,5 million category 1 vine seedlings per year. In order to carry out this task, the sovkhozes will have to plant 250 hectares of new vineyards a year, for which no land suitable for growing planting material is available. In view of the above, please urgently examine the issue of the cultivation of planting material by winemaking sovkhozes and allocate 750 hectares of land suitable for the cultivation of planting material (based on a three-field crop rotation) for the following sovkhozes: Uzhgorod (100 ha), Serednie, Mukachevo (150 ha), Berehove (150 ha), Muzhiyevo (110 ha), Vynohradiv (120 ha) [...] (TRSA. F. P-179. Op. 1. Od. zb. 4058. Ark. 36)».
} 
Significant amounts of money were needed to carry out these tasks. A total of $59,7 \mathrm{mln}$ roubles was needed to plant new vineyards in the kolkhozes and sovkhozes included in the seven-year plan (Шепа, 1971: 33).

The economic activities of the Transcarpathian wine trust between 1960 and 1961 were estimated at $58,7 \mathrm{mln}$ roubles, which included soil preparation, the planting of new plantations, the care of young plants - a total of $48,8 \mathrm{mln}$ roubles, as well as $1 \mathrm{mln}$ roubles to purchase necessary agricultural machinery and an additional $8,9 \mathrm{mln}$ to build housing.

The Transcarpathian Wine Trust was allowed $11 \mathrm{mln}$ roubles for expansion and development. However, this required $37,7 \mathrm{mln}$ roubles. Therefore, in a letter to the Council of Ministers, the Transcarpathian County Committee requested that in 1960, 37,7 mln roubles be allocated to the Transcarpathian Wine Trust for the development of agricultural production in the sovkhozes (TRSA. F. P-179. Op. 1. Od. zb. 4821. Ark. 22).

After the expansion of the areas for growing fruits and berries, as soon as the plants started to grow, the problems with fruit processing began. The existing technical base of the processing companies could not meet the needs. According to the calculations, eight grape processing plants with a total capacity of $51000 \mathrm{t}$ of grapes in each season had to be built in the region, as well as one plant with a capacity of 150000 decaliter grape juice. By Resolution № 402 of March 22, 1960, the Council of Ministers of the Soviet Socialist Republic of Ukraine authorized the construction of a grape juice plant in the region in 1962 (TRSA. F. P-179. Op. 1. Od. zb. 4821. Ark. 5-23).

According to an inventory of the region's vineyards in 1960, there were 13,5 mln empty slots on the vineyards, and the rate of thinning was $25 \%$. According to experts' calculations, the kolkhozes and sovkhozes of the region lost $200000 \mathrm{q}$ of grapes a year due to the thinning alone. In fact, almost 4000 ha of vacant land were cultivated in vain

In a letter to the USSR Council of Ministers, the head of the Transcarpathian County Agricultural Directorate expressed his concerns about the state of viticulture ${ }^{8}$.

Various organizations in the party and the region were aware of the shortcomings in fruit production and viticulture. However, nothing was done other than criticizing the organizational shortcomings in the governance of the sectors. For example, Mozgovy I., Second Secretary of the Transcarpathian County Committee of the UCP, addressed the following

\footnotetext{
${ }_{8}^{8} \mathrm{He}$ emphasized that: «In their calculations for the further development of viticulture, the kolkhozes and sovkhozes in Transcarpathia, based on the results of an inventory of perennial plantations, concluded that 15 million plants were missing out of the total 36 million - to completely eliminate the depletion of these vineyards within three years and to make them fully operational is much more cost-effective than increasing the area under vineyards (TRSA. F. P-179. Op. 1. Od. zb. 4821. Ark. 27)».
}

issuesin his speech at the agronomist council held on 6 April $1963^{9}$.

Districts, kolkhozes, and sovkhozes were required to plant orchards and vineyards under the seven-year plan (1959-1965). The area of orchards had to be expanded in all 13 districts and the area of vineyards in 6 districts. By 1965, the Khust and Tyachiv districts had to have the largest orchard areas, i. e. 15000 ha. In the mountain areas, i. e. in the districts of Velykyi Bereznyi and Perechyn, the area of orchards was expanded to 3000 ha, and in the district of Rakhiv to 5000 ha (TRSA. F. P-179. Op. 1. Od. zb. 3354. Ark. 43).

The economic indicators attributed to the fact that the agriculture of the countryside in need of subsidization was, in fact, overestimated, so on 26 February 1958, by decree of the Presidency of the Supreme Soviet of the USSR, Transcarpathia was awarded the Order of Lenin "as a recognition for the success in the production and stockpiling of cereals, grapes, fruit, milk, wool and other agricultural products (Tokár et al, 2011: 153)”. The award was presented by Katerina Furtseva, Secretary of the Central Committee of the CPSU, in Uzhgorod, where she came from Moscow specifically for this purpose. At the same time, Furtseva also handed Yuri Pitra the gold star of the Hero of Socialist Labor. Furtseva also brought with her Nikita Khrushchev's personal gift to Transcarpathia: a portrait of a working woman (Oficinszkij, 2010a: 232). The people of Transcarpathia happily welcomed the recognition ${ }^{10}$ stated the county committee and county council of the Communist Party of Ukraine, in the letter of tratitude sent on 20 May 1958 to the head of the Central Committee of the CPSU, Chairman of the Supreme Soviet of the USSR, and the Council of Ministers of the USSR (TRSA. F. 1. Op. 1. Spr. № 3213. Ark. 1-15).

\footnotetext{
${ }_{9}$ «The state and party inspectorates are currently monitoring the state of fruit production and viticulture in the county. 3000 hectares of orchards and 25000 hectares of vineyards are missing, and nowhere can we find any documents about where they were planted, what was planted, and so on. We have far fewer orchards today than we did in 1953. We have wasted large sums of money, and all because of ill-considered management, right in the kolkhozes (TRSA. F. P-179. Op. 1. Od. zb. 4069. Ark. 79-81)».

${ }^{10} \ll[\ldots]$ For the excellent performance of their work, 3000 workers from our young Soviet region received the highest government honors. Thirty agricultural professionals of Transcarpathia have been awarded the honorary title of Hero of Socialist Work, and the brigade leader of the Lenin Kolkhoz in the Mukachevo district, Anna Mikhailovna Ladányi has received this high honor twice. We are proud of our heroes and honorees. However, it is an even greater joy for us that our county receives the highest honor, which is the Lenin Order of Merit. Transcarpathia lined up with the leading counties of Soviet Ukraine [...] In response to the high-level government award, collective farm employees in Transcarpathia undertake to produce this year: 17 centners of grain, 30 centners of corn, 42 centners of grapes per hectare; and 34 centners of meat, 187 centners of milk and 91 kilograms of wool for every 100 hectares of agricultural land. Furthermore, compared to the previous year, the cost of working days is reduced in the production of $1-1$ centners of products: by $10 \%$ for grain and by $15 \%$ for meat [...]» (TRSA. F. 1. Op. 1. Spr. № 3213. Ark. 1-15).
} 


\section{Conclusions}

The key areas of crop production in Transcarpathia during the time of $\mathrm{N}$. Khrushchev were domestication of tea and citrus plants, the great Party cereal (corn) program, and growing of vegetables, fruits and grapes. The plan for the domestication of tea and citrus plants failed because the kolkhozes were unable to meet the plans regarding the tea plantations, mostly due to frost damage to the plants. A number of problems arose in corn production as well. Orcharding and viticulture were relatively successful even in the mountain areas. Plan-based Soviet management was unable to satisfy all needs of Transcarpathian crop production during the time of N. Khrushchev.

\section{BIBLIOGRAPHY}

1. Brenzovics L. Kárpátalja történetének korszakai és gazdasági - tarsadalmi helyzete a XX. Században. Kárpátalja / Szerk. Baranyi B. Pécs - Budapest: MTA Regionális Kutatások Központja, 2009. O1. 75-106.

2. Csanádi G. Sorsfordító évek sodrásában. Uzhhorod: Poli Print, 2004. 335 ol.

3. Krausz T. A rövid XX század. A Szovjetunió története 1914-1991. Budapest: Kossuth Kiadó, 2008. 224 ol.

4. Kun M. Kelet-Európa az 1950-as években: Reformok és visszarendeződés // Mindentudás Egyeteme, 2006. Október 16. URL: https://mult-kor.hu/cikk.php?id=15002

5. Oficinszkij R. A szovjet időszak sajátosságai Kárpátalja történetében // Kárpátalja 1919-2009 / Szerk. Fedinec C., Vehes M. Budapest: Argumentum, 2010. O1. 242-244.

6. Oficinszkij R. Mezőgazdaság // Kárpátalja 1919-2009 / Szerk. Fedinec C., Vehes M. Budapest: Argumentum, 2010. Ol. 274-284.

7. Tokár M. et al. Kárpátalja évszámokban 1867-2010. Uzgorod: Ungvári Nemzeti Egyetem Politikai Regionalizmus Kutatóintézete, 2011. 312 ol.

8. Баран В. К. Україна після Сталіна. Нарис історії 1953-1985 рр. Львів: Свобода, 1992. 124 с.

9. Білоусов В. та ін. Нариси історії Закарпатської обласної партійної організації. Ужгород : Карпати, 1980.317 с.

10. Медведев Р. Н.С. Хрущев. Политическая биография. Москва : Книга, 1990. 68 с.

11. Народне господарство Закарпатської області. Статистичний збірник. Ужгород : Закарпатське обласне видавніцтво, 1957. 168 с.

12. Шепа В. Проблеми розвитку виноградарства Закарпаття. Київ : Урожай, 1972. 195 с.

13. Шманько Г. et al. Региональные аспекты приграничного экономического сотрудничества СССР со странами СЭВ / Раздел Ужгородского отдела Института социальных и экономических проблем зарубежных стран АН УССР. Москва, 1983. 190 с.

\section{REFERENCES}

1. Brenzovics L. Kárpátalja történetének korszakai és gazdasági - tarsadalmi helyzete a XX. Században [The Epochs and Economic and Social Situation of the History of Transcarpathia in the 20 th Century]. Kárpátalja / Szerk. Baranyi B. Pécs - Budapest: MTA Regionális Kutatások Központja, 2009. O1. 75-106. [in Hungarian].

2. Csanádi G. Sorsforditó évek sodrásában [In the Turn of Fateful Years]. Uzhhorod: Poli Print, 2004.335 ol. [in Hungarian].

3. Krausz T. A rövid XX század. A Szovjetunió története 1914-1991 [The short XX Century. History of the Soviet Union 1914-1991]. Budapest: Kossuth Kiadó, 2008. 224 ol. [in Hungarian].

4. Kun M. Kelet-Európa az 1950-as években: Reformok és visszarendeződés [Eastern Europe in the 1950's: Reforms and Reorganization]. Mindentudás Egyeteme, 2006. Október 16. URL: https://mult-kor.hu/cikk.php?id=15002 [in Hungarian].

5. Oficinszkij R. A szovjet idöszak sajátosságai Kárpátalja történetében [Peculiarities of the Soviet Period in the History of Transcarpathia]. Kárpátalja 1919-2009 / Szerk. Fedinec C., Vehes M. Budapest: Argumentum, 2010. O1. $242-244$. [in Hungarian].

6. Oficinszkij R. Mezőgazdaság [Agriculture]. Kárpátalja 1919-2009 / Szerk. Fedinec C., Vehes M. Bp. 2010. Ol. 274-284.

7. Tokár M. et al. Kárpátalja évszámokban 1867-2010 [Transcarpathia in the Years 1867-2010]. Uzgorod: Ungvári Nemzeti Egyetem Politikai Regionalizmus Kutatóintézete, 2011. 312 ol. [in Hungarian].

8. Baran V. K. Ukraina pislia Stalina. Narys istorii 1953-1985 rr. [Ukraine after Stalin. An Essay on the History of 1953-1985]. Lviv: Freedom, 1992. 124 p. [in Ukrainian].

9. Bilousov V. ta in. Narysy istorii Zakarpatskoi oblasnoi partiinoi orhanizatsii. [Essays on the History of the Transcarpathian Regional Party Organization] Uzhhorod: Carpathians, 1980. 317 p. [in Ukrainian].

10. Medvedev R. N. S. Hrushhev. Politicheskaja biografija [N. S. Hrushhev. Political Biography]. Moskow: Book, 1990. 68 p. [in Russian].

11. Narodne hospodarstvo Zakarpatskoi oblasti. Statystychnyi zbirnyk [People Household of Transcarpathian Region. Statistical Collection]. Uzhhorod: Transcarpathian Regional Publishing House, 1957. 168 p. [in Ukrainian].

12. Shepa V. Problemy rozvytku vynohradarstva Zakarpattia [Problems of Viticulture Development in Transcarpathia]. Kyiv: Crops, 1972. 195 p. [in Ukrainian]. 
Váradi N. The plant cultivation situation of Transcarpathia in the Khrushchev era (1953-1964)

13. Shman'ko G. et al. Regional'nye aspekty prigranichnogo jekonomicheskogo sotrudnichestva SSSR so stranami SJeV / Razdel Uzhgorodskogo otdela Instituta social'nyh i jekonomicheskih problem zarubezhnyh stran AN USSR [Regional aspects of cross-border economic cooperation between the USSR and the CMEA countries / Section of the Uzhgorod Department of the Institute of Social and Economic Problems of Foreign Countries of the Academy of Sciences of the Ukrainian SSR]. Moscow, 1983. 190 p. [in Russian]. 